\title{
Light and Electron Microscopic Study on the Possible Protective Effect of Nigella Sativa Oil on Cisplatin Hepatotoxicity in Albino Rats
}

\author{
Original \\ Article \\ Maysara M. Salem ${ }^{1}$ and Zainab M. Altayeb ${ }^{2}$ \\ ${ }^{1}$ Histology and Cell Biology Department, Faculty of Medicine, Benha University, Benha, Egypt \\ ${ }^{2}$ Histology and Cell Biology Department, Faculty of Medicine, Helwan University, Helwan, \\ Egypt
}

\begin{abstract}
Introduction: Cisplatin has a potent anti-tumor action and it has been associated with several toxic side effects. Nigella sativa (NS) oil has an antioxidant and protective effects against side effects of many drugs.

Aim: This study aimed to investigate the effects of cisplatin on the liver of rats and the protective effect of NS oil both histologically (LM and EM) and biochemically (serum ALT \& AST).

Material and methods: Thirty five adult male rats were used in this study and were divided into 4 groups; group I: as a control group, 10 rats were used and divided equally to negative and positive controls, group II: (5 rats) received NS oil $2 \mathrm{ml} / \mathrm{kg}$ body weight (BW) by gastric tube daily for 10 days. The group III: (10 rats) received cisplatin $1.5 \mathrm{mg} / \mathrm{kg}$ BW intraperitonial (i.p.) daily for 7 days and group IV: (10 rats) received cisplatin $1.5 \mathrm{mg} / \mathrm{kg}$ BW (i.p.) daily for 7 days and NS oil $2 \mathrm{ml} / \mathrm{kg} \mathrm{BW}$ by gastric tube daily for 10 days starting 3 days before cisplatin administration. Twenty four hours after the end of experiment, blood samples and liver specimens were obtained from animals in all groups and prepared for examinations.

Results: The results revealed that group II was nearly as group I. Group III revealed by LM cytoplasmic vacuolation, pyknotic nuclei and aggregation of inflammatory cells in some portal tracts and surrounding central veins. By EM, hepatocytes revealed some pyknotic nuclei and degenerated mitochondria. Some area of the cytoplasm showed rarefaction and vacuoles. Also there was a significant increase in both ALT \& AST levels. Group IV revealed amelioration of these changes.

Conclusion: NS oil ameliorates the hepatotoxic effects of cisplatin.
\end{abstract}

Key Words: Cisplatin, nigella sativa, thymoquinone, hepatotoxicity.

Received: 20 December 2016, Accepted: 30 April 2017

Corresponding Author: Maysara M. Salem , Tel.: +201064470443, E-mail: maysara.m.salem@gmail.com

ISSN: 1110-0559, March 2017, Vol. 40, No. 1

\section{INTRODUCTION}

Cisplatin is one of the most frequently used antineoplastic agents. Cisplatin has major antitumor activity in a broad range of solid tumors, including lung cancer, esophageal and gastric cancer, cholangiocarcinoma, head and neck cancer, and genitourinary cancers, particularly testicular, ovarian, and bladder cancer $^{[1]}$. It may act similarly to the alkylating agents. It kills malignant cells in all stages of the cell cycle and hinders DNA synthesis and functions through binding DNA via the formation of interstrand and intrastrand cross-links ${ }^{[2]}$. Cisplatin treatment has been associated with several toxic side effects, including myelosuppression, nephrotoxicity, oral mucositis, ototoxicity, peripheral neuropathy, severe nausea, severe vomiting, thromboembolism and tumor lysis syndrome $e^{[3]}$.
The usage of cisplatin has been accompanied by many side effects but the most dangerous one is nephrotoxicity, which limits its clinical use. Also, it can cause hepatotoxic effect which is less common ${ }^{[4]}$. However, there is little information about the exact mechanism regarding its hepatotoxic effect ${ }^{[5]}$.

The black seed, NS, has been shown to contain more than $30 \%$ of fixed oil. The NS oil extracts and its major active ingredient, thymoquinone (TQ) have many beneficial biological activities such as antioxidant for many free radicles ${ }^{[6,7]}$ and anti-inflammatory effects ${ }^{[6,8]}$.

The extracts oftheblackseeds havemany other therapeutic properties such as bronchodilatation, immunomodilative ${ }^{[9]}$, antibacterial ${ }^{[10]}$, anti-Schistosomal effect ${ }^{[11]}$ hypotensive $^{[12]}$, antidiabetic $^{[13]}$, hepatoprotective ${ }^{[14,15]}$, gastroprotective ${ }^{[16]}$, 
antihistaminic, antioxidative ${ }^{[17]}$ anticancer properties ${ }^{[18]}$ and neuroprotective ${ }^{[19]}$. TQ has been shown to attenuate cisplatin nephrotoxicity ${ }^{[20]}$, tetrachloride hepatotoxicity ${ }^{[21]}$ and rheumatoid arthritis ${ }^{[2]}$.

As NS oil and its active component TQ, has been proposed to prevent many toxic effects on the cells and tissues. Therefore, this study aimed to investigate hepatotoxicity of cisplatin and the possible protective effect of NS oil on cisplatin-induced hepatotoxicity by evaluating histological changes, by both LM and EM. In addition, biochemical analysis of some sensitive liver function tests (serum ALT and AST) were performed to verify the correlation between histological and biochemical changes.

\section{PATIENTS AND METHODS}

\section{Animals:}

The present study was carried out on 35 normal adult male albino rats, aged $3-4$ months and their body weight ranged between 200 and 230 gms. They were obtained from the animal house of Moshtohor Faculty of Veterinary Medicine, Benha University and acclimatized to the laboratory conditions. They were housed in plastic cages with mesh wire covers under the prevailing atmospheric conditions and were given food and water ad libitum. The rats were sacrificed according to the Ethics Committee Recommendations of Benha University.

\section{Drugs:}

Cisplatin: is produced by Oncotec Pharma Produktion GmbH, Am Pharmapark, Germany. The tradetional name is Mylan, it is produced in vials containing $10 \mathrm{ml}$ or $25 \mathrm{ml}$ and its concentration is $1 \mathrm{mg} / \mathrm{ml}$.

NS oil: is produced by Isis company (Egypt).

The animals were divided as follow:

Group I control group: included 10 animals divided into:

Subgroup IA as a negative control (5 rats), they were left without intervention. Subgroup IB as a positive control (5 rats) each animal was given $0.5 \mathrm{ml}$ of $0.9 \%$ normal saline (vehicle for cisplatin) intraperitoneal (i.p.) daily for 7 days.

Group II: included 5 animals, each animal was given NS oil $2 \mathrm{ml} / \mathrm{kg}$ BW by gastric tube daily for 10 days. The animals were fasted 2 hours before NS oil administration ${ }^{[23]}$.

Group III: included 10 animals, each animal received cisplatin $1.5 \mathrm{mg} / \mathrm{kg} \mathrm{BW}$ (i.p.) daily for 7 days ${ }^{[24]}$.
Group IV: included 10 animals, each animal received cisplatin $1.5 \mathrm{mg} / \mathrm{kg}$ BW (i.p.) daily for 7 days and NS oil $2 \mathrm{ml} / \mathrm{kg}$ BW by gastric tube daily for 10 days starting 3 days before cisplatin administration. Twenty four hours after the end of experiment, animals in all groups were anaesthetized by ether inhalation, then dissected and blood samples were obtained from the left ventricle by canula, then animals were perfused by saline $(0.9 \%)$ then perfused by $2.5 \%$ glutaraldehyde for fixation ${ }^{[25]}$

\section{A) Histological study:}

Liver specimens of each animal were collected from right lobe and divided into two parts. The first part was fixed in $10 \%$ formal saline, dehydrated, cleared and embedded in paraffin wax. Sections of $5 \mu \mathrm{m}$ thick were cut and stained with haematoxylin and eosin (H\&E) for light microscope (LM) studies ${ }^{[26]}$. The second part was proceded for electron microscopic (EM) examination as follow: Four to five small pieces were taken from the liver of each rat and were fixed in glutaraldehyde and osmium tetroxide. The fixed parts were dehydrated and embedded in Epon 812. Semithin sections, $1 \mu \mathrm{m}$ thick were cut and stained with toluidine blue and examined by LM to choose the selected areas for proper orientation. Ultrathin sections were stained by uranyl acetate and lead citrate ${ }^{[27]}$. The EM study was performed with a Jeol JEM-100 SX electron microscope in EM Unit, Faculty of Medicine, Tanta University.

\section{B) Biochemical study:}

Three ml of blood samples were obtained from the left ventricle of each rat. The collected blood samples were incubated at $37^{\circ} \mathrm{C}$ until blood clotted and then centrifuged to separate the serum to be used for estimation of the following biochemical values:

1- Alanine aminotransferase (ALT).

2- Aspartate aminotransferase (AST).

Estimation was done spectrophotometrically using the reagents of commercial kits of Biosystem products and laboratory reagents Co. (Spain) in Clinical Pathology Department, Faculty of Medicine, Tanta University.

Statistical evaluation of the biochemical results was performed by using SPSS software (version 20; SPSS Inc. Chicago, Illinois, USA). Values were expressed as mean \pm SD. Differences were assessed using Student's t-test. Values of P less than 0.05 were considered statistically significant. 


\section{RESULTS}

\section{A) Histological study:}

\section{Group I\&II:}

Histological examination of the liver in rats of groups I and II showed nearly the same structures.

Light microscopic examination revealed the normal architecture of classical hepatic lobules. They showed central veins and plates of liver cells radiating from them. The liver plates were separated from each other by irregular blood sinusoids. The liver cells were polyhedral in shape with acidophilic cytoplasm and large rounded vesicular nuclei (Fig. 1). At the periphery of hepatic lobule portal tracts were present, each tract contained branches of portal vein, hepatic artery and bile duct (Fig. 2)

Electron microscopic examination showed the normal ultrastructure. The hepatocytes contained rounded euchromatic nuclei with nuclear membranes and nucleoli. The cytoplasm was rich in cell organelles as mitochondria, rough endoplasmic reticulum and lysosomes (Fig. 3). Between adjacent hepatocytes, bile canaliculi were present with microvilli project inside the lumen and junctional complexes sealed off these spaces from the remaining extracellular space (Fig. 4).

\section{Group III:}

LM examination of this group revealed focal affection of hepatic tissue. Some hepatocytes showed vacuolated cytoplasm and small dark nuclei. Inflammatory cells were present surrounding the central veins and at the portal areas (Figs. 5 and 6).

EM examination of the liver sections revealed heterochromatic nuclei with irregular nuclear membranes (Figs. 7 and 11). Some nuclei appeared pyknotic with dilated nuclear envelop (Figs 8 and 9). Some sections showed electron dense mitochondria with indistinct cristae (Fig. 7). Other sections showed moderate electron dense mitochondria with disorganized cristae or even complete disappearance of cristae (cristolysis) (Figs. 8- 10). Many autolysosome can be encountered in some sections (Figs. 7 and 10). While other sections showed plenty of lipid droplets (Fig. 11). In addition, some areas of the cytoplasm showed rarefaction (Figs. 9 and 10).

\section{Group IV:}

LM examination of liver sections of this group revealed that most of the sections showed a histological picture nearly comparable to the control. Some sections showed dilatation of blood sinusoids (Fig. 12). Some hepatocytes appeared vacuolated with pyknotic nuclei (Figs. 12 and 13). Few inflammatory cells were noticed at the portal areas (Fig. 13)

EM examination of liver sections revealed that a histological picture of most of the hepatocytes comparable to that of the control group. Hepatocytes have euchromatic nuclei with regular nuclear membranes. The cytoplasm was studded with rough endoplasmic reticulum, mitochondria, and some lysosomes. There were also abundant glycogen granules and few lipid droplets (Fig. 14).

\section{B) Biochemical study:}

Control group showed serum level of ALT (40 \pm 3.5$)$ $\mathrm{IU} / \mathrm{L}$ and AST $(41 \pm 2.8) \mathrm{IU} / \mathrm{L}$

Animals received (NS) oil had mild insignificant increase in ALT $(42 \pm 4) \mathrm{IU} / \mathrm{L}$ and AST $(45 \pm 2.3) \mathrm{IU} / \mathrm{L}$ as compared to control rats $(p>0.05)$.

Animals received cisplatin showed a highly significant increase in ALT $(77 \pm 4.1) \mathrm{IU} / \mathrm{L}$ and AST $(112 \pm 4.6) \mathrm{IU} / \mathrm{L}$ as compared to control rats $(p<0.001)$.

Animals received cisplatin and NS oil showed an insignificant increase in ALT $(45 \pm 2.8) \mathrm{IU} / \mathrm{L}(p>0.05)$ and significant increase in AST $(68 \pm 4.1) \mathrm{IU} / \mathrm{L}(p<0.05)$ as compared to control rats (Table 1 and Histogram 1). 
Table 1: The serum level of ALT \& AST in groups I, II, III and IV.

\begin{tabular}{|c|c|c|c|}
\hline Groups & & ALT (IU/L) & AST (IU/L) \\
\hline $\begin{array}{l}\text { Group I } \\
\text { (Control) }\end{array}$ & $\mathrm{X} \pm \mathrm{SD}$ & $40 \pm 3.5$ & $41 \pm 2.8$ \\
\hline \multirow{4}{*}{$\begin{array}{l}\text { Group II } \\
\text { (Nigella saliva) }\end{array}$} & $\mathrm{X} \pm \mathrm{SD}$ & $42 \pm 4$ & $45 \pm 2.3$ \\
\hline & $\mathrm{t}$ & 1.1 & 1.3 \\
\hline & $\mathrm{P}$ & $>0.05$ & $>0.05$ \\
\hline & Sig. & Non & Non \\
\hline \multirow{4}{*}{$\begin{array}{l}\text { Group III } \\
\text { (Cisplatin) }\end{array}$} & $\mathrm{X} \pm \mathrm{SD}$ & $77 \pm 4.1$ & $112 \pm 4.6$ \\
\hline & $\mathrm{t}$ & 5.2 & 7.1 \\
\hline & $\mathrm{P}$ & $<0.001$ & $<0.001$ \\
\hline & Sig. & Highly & Highly \\
\hline \multirow{4}{*}{$\begin{array}{l}\text { Group IV } \\
\text { (Cisplatin \& Nigella saliva) }\end{array}$} & $\mathrm{X} \pm \mathrm{SD}$ & $45 \pm 2.8$ & $68 \pm 4.1$ \\
\hline & $\mathrm{t}$ & 1.8 & 4.7 \\
\hline & $\mathrm{P}$ & $>0.05$ & $<0.05$ \\
\hline & Sig. & Non & significant \\
\hline
\end{tabular}

$\mathrm{X}=$ Mean values.

$\mathrm{SD}=$ Standard Deviation

Sig. $=$ Significance.

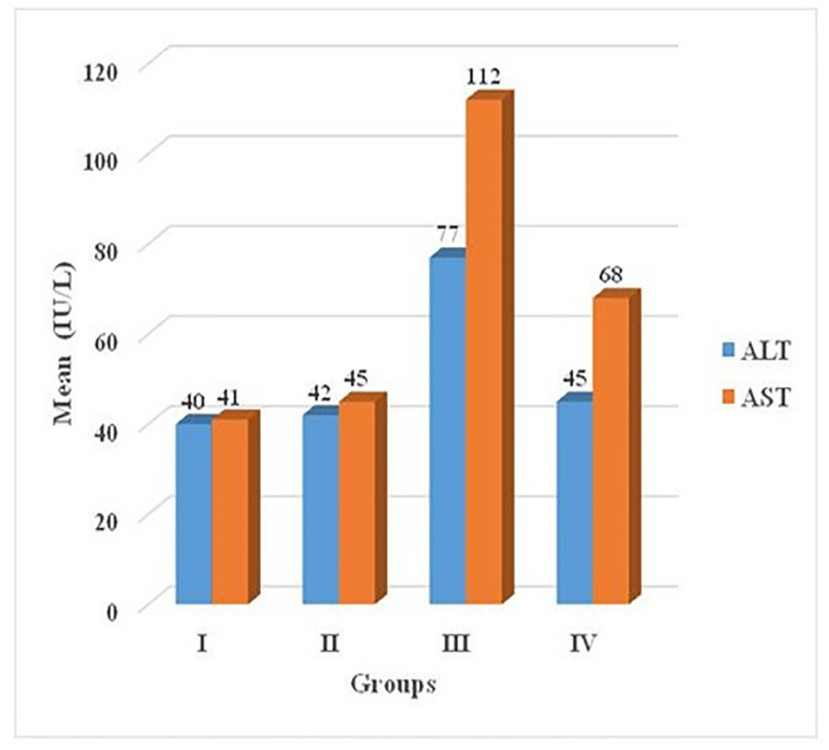

Histogram 1: Showing the mean of ALT and AST (IU/L) in groups I, II, III and IV.

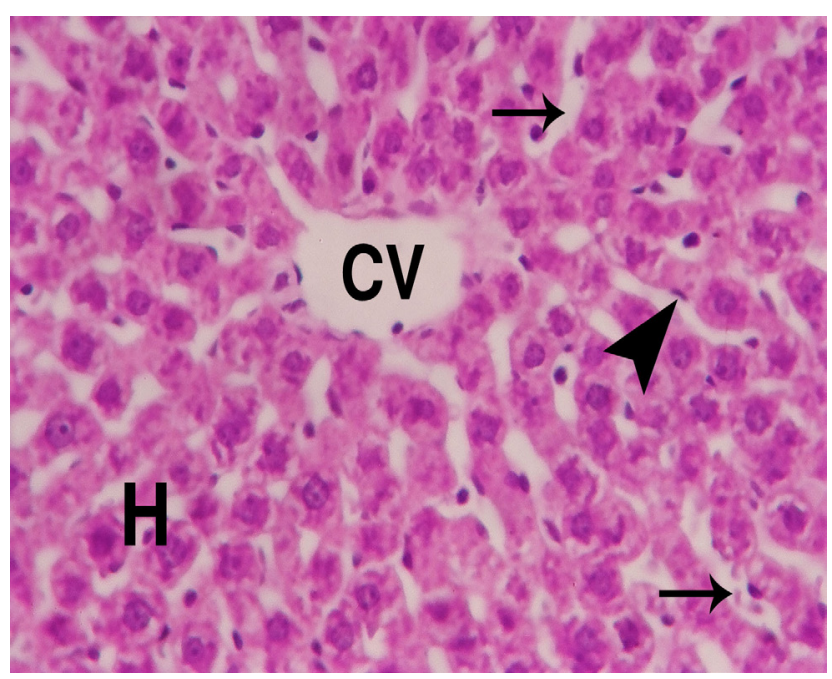

Fig. 1: A photomicrograph of section in the liver of a rat of control group showing blood sinusoids $(\uparrow)$ lined by endothelial cells (arrow head) intervening with hepatic cords of hepatocytes $(\mathrm{H})$, surrounding a central vein $(\mathrm{CV})$.

$(\mathrm{H} \& \mathrm{E} \times 400)$ 


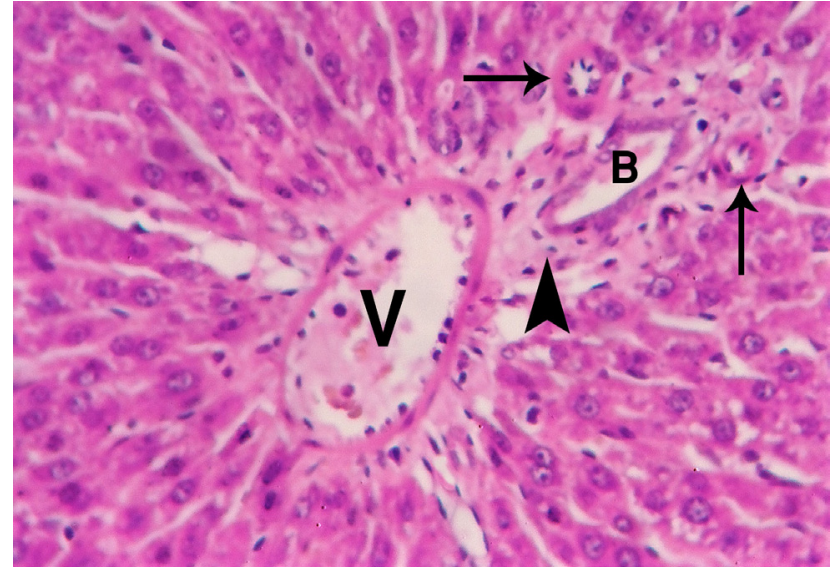

Fig. 2: A photomicrograph of a section in the liver of a control rat showing a portal tract with branches of hepatic artery $(\uparrow)$, portal vein $(\mathrm{V})$ and bile duct $(\mathrm{B})$ surrounded by connective tissue (arrow head).

(H \& E x 400)

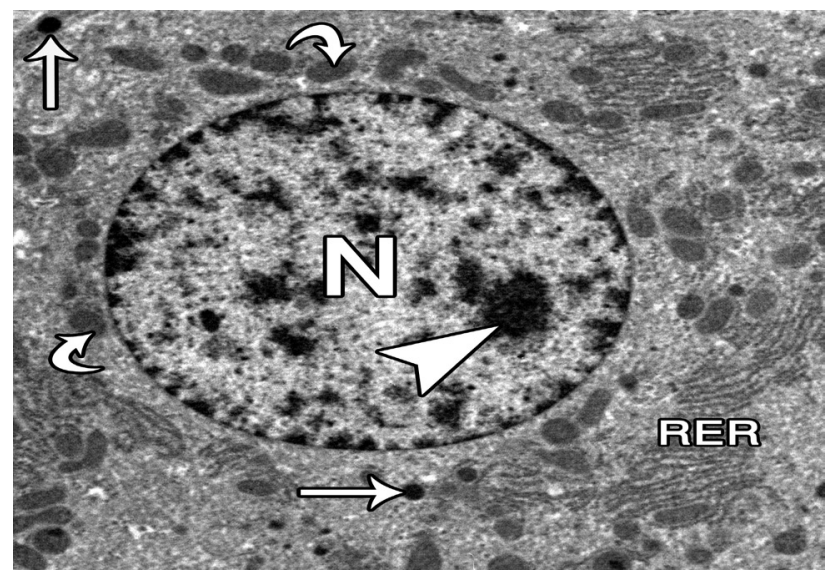

Fig. 3: An electron micrograph of a section in the liver of a control rat showing hepatocyte. The nucleus $(\mathrm{N})$ is rounded in shape with nuclear membrane, nucleolus (arrow head) and chromatin. The cytoplasm is rich in cell organelles as mitochondria (bent arrows) rough endoplasmic reticulum (RER) and lysosomes $(\uparrow)$.

(x 11700)

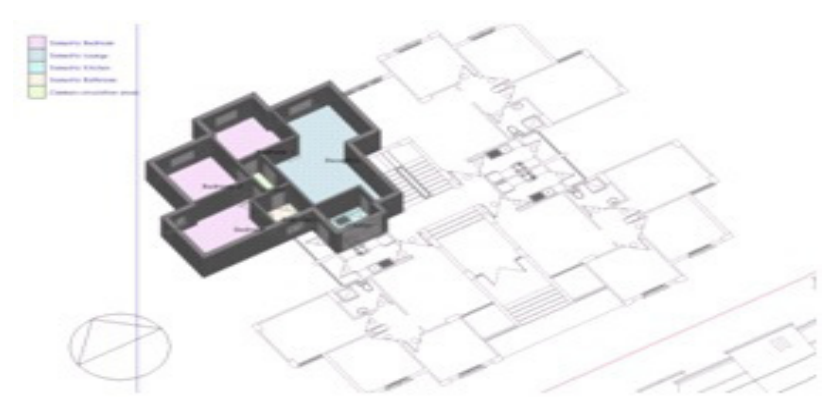

Fig. 4: An electron micrograph of a section in the liver of a control rat showing two adjacent hepatocytes. Notice bile canaliculus (arrow head) containing microvilli in its lumen, junctional complexes $(\uparrow)$ and mitochondria (bent arrows).

(x 17500)

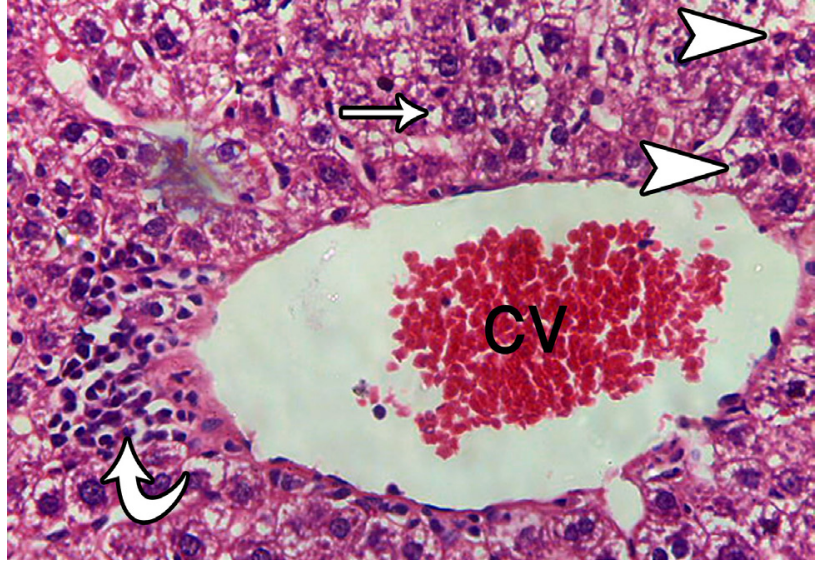

Fig. 5: A photomicrograph of a section in a liver of a rat given cisplatin for one week showing dilated congested central vein (CV). Some hepatocytes show vacuolated cytoplasm (arrow heads) and pyknotic nuclei $(\uparrow)$. Inflammatory cells (bent arrow) are present at one side of the central vein. (H \& E x 400)

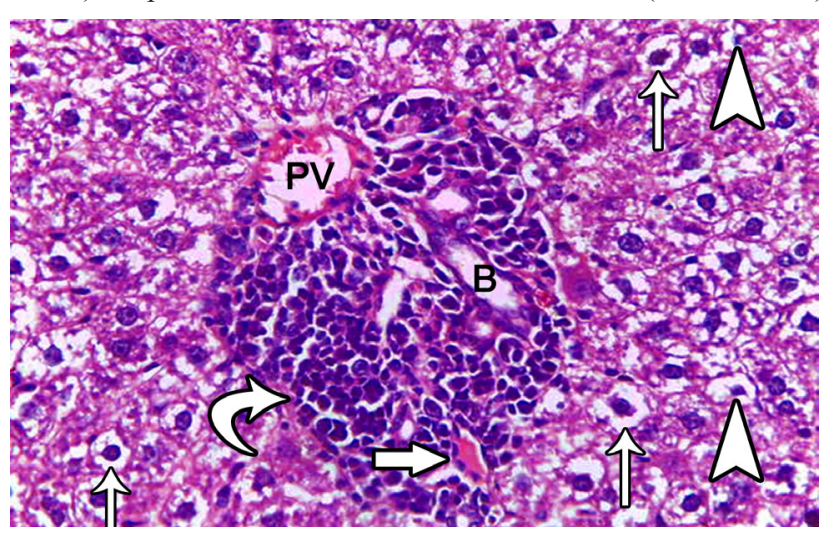

Fig. 6: A photomicrograph of a section in the liver of a rat given cisplatin for one week showing inflammatory cells in the portal area (bent arrow), branches of portal vein (PV), hepatic artery (thick arrow) and bile duct (B). Hepatocytes show cytolpasmic vacuolation $(\uparrow)$ and small dark nuclei (arrow heads).

( H \& E x 400)

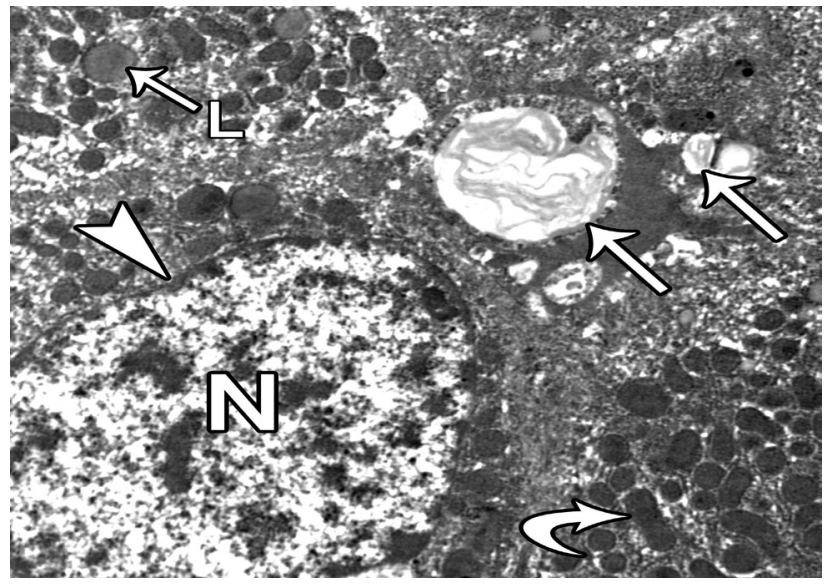

Fig. 7: An electron micrograph of a section in the liver of a rat given cisplatin showing the nucleus $(\mathrm{N})$ with irregular nuclear membrane (arrow head), membranous autolysosome ( $\uparrow$ ), lysosome (L) and electron dense mitochondria (bent arrow).

(x 11700) 


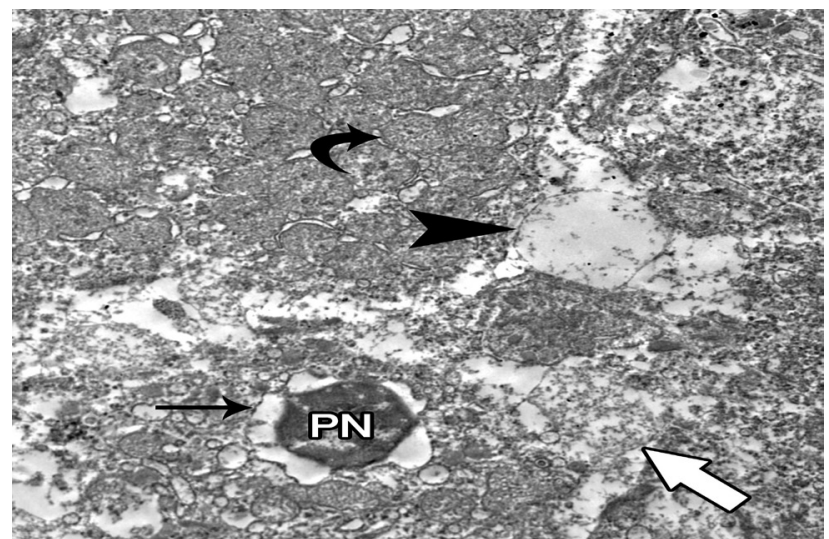

Fig. 8: An electron micrograph of a section in the liver of a rat given cisplatin showing a pyknotic nucleus $(\mathrm{N})$ with dilated nuclear envelop ( $\uparrow$ ), numerous mitochondria (bent arrow). Some mitochondria show disorganized cristae (thick arrow) and other show cristolysis (arrow head).

(x 11700)

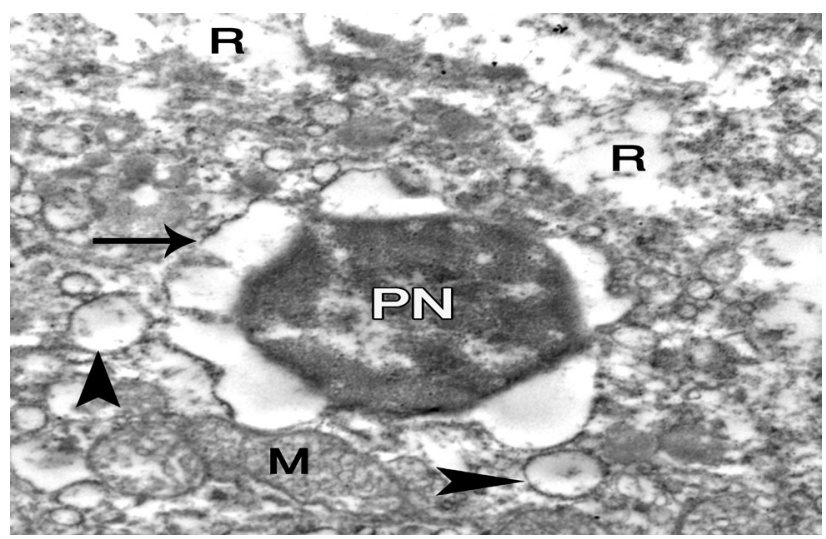

Fig. 9: An electron micrograph of the previous figure with a larger magnification showing a pyknotic nucleus $(\mathrm{N})$ with dilated irregular nuclear envelop $(\uparrow)$, mitochondrion (M), some mitochondria showing cristolysis (arrow heads) and some areas of the cytoplasm show rarefaction (R).

(x 29200)

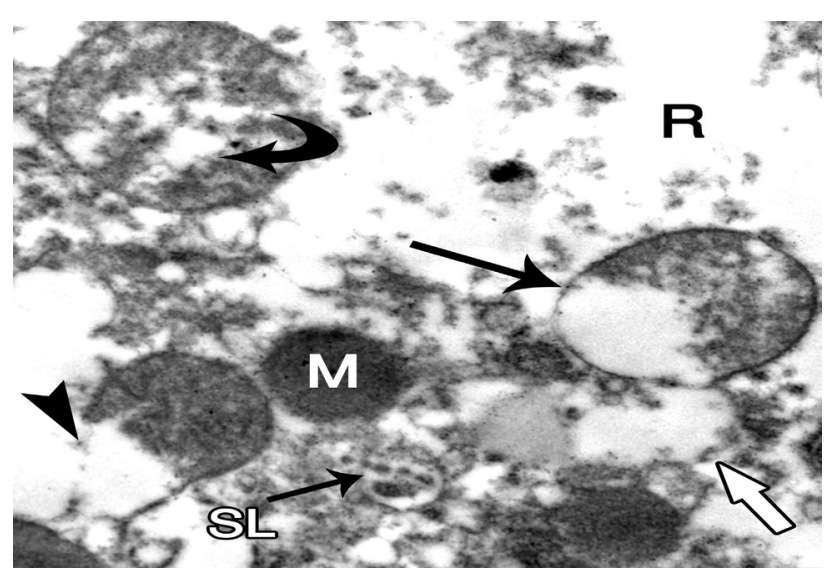

Fig. 10: An electron micrograph of a section in the liver of a rat given cisplatin showing complete (thick arrow) and partial $(\uparrow)$ degenerated mitochondria with cristolysis, mitochondrion with a partial loss of membranes (arrow head), mitochondrion with cavities (bent arrow), secondary lysosome (SL) and rarified cytoplasm (R).

(x 46800)

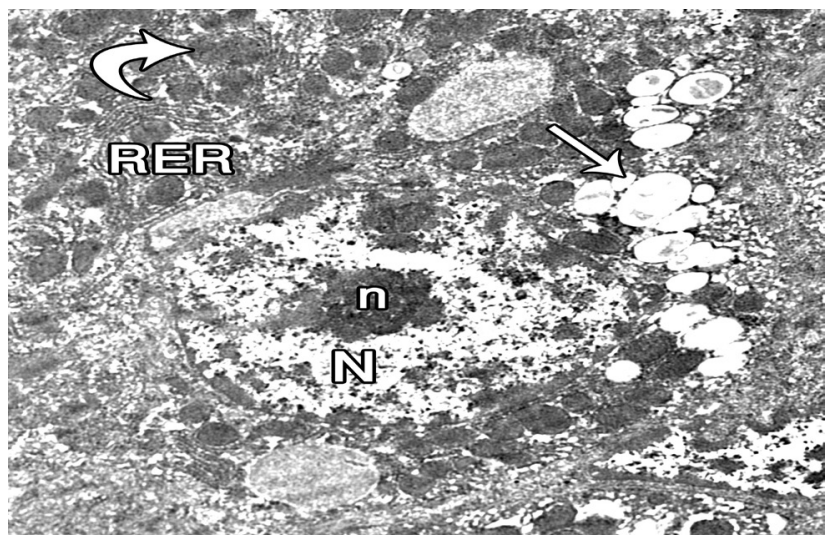

Fig. 11: An electron micrograph of a section in the liver of a rat given cisplatin showing nucleus $(\mathrm{N})$ with irregular nuclear membrane, nucleolus (n), RER, mitochondria (bent arrow) and lipid droplets $(\uparrow)$.

(x 11700)

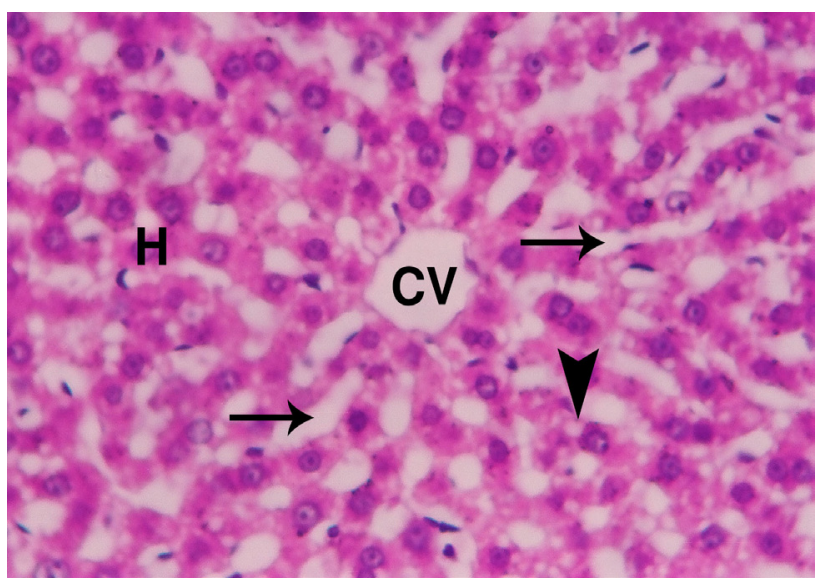

Fig. 12: A photomicrograph of a section in the liver of a rat of group IV showing dilated blood sinusoids $(\uparrow)$ intervening with cords of hepatocytes $(\mathrm{H})$ surrounding a central vein $(\mathrm{CV})$. Some hepatocytes show vacuolations (arrow head). (H\&E X x 400)

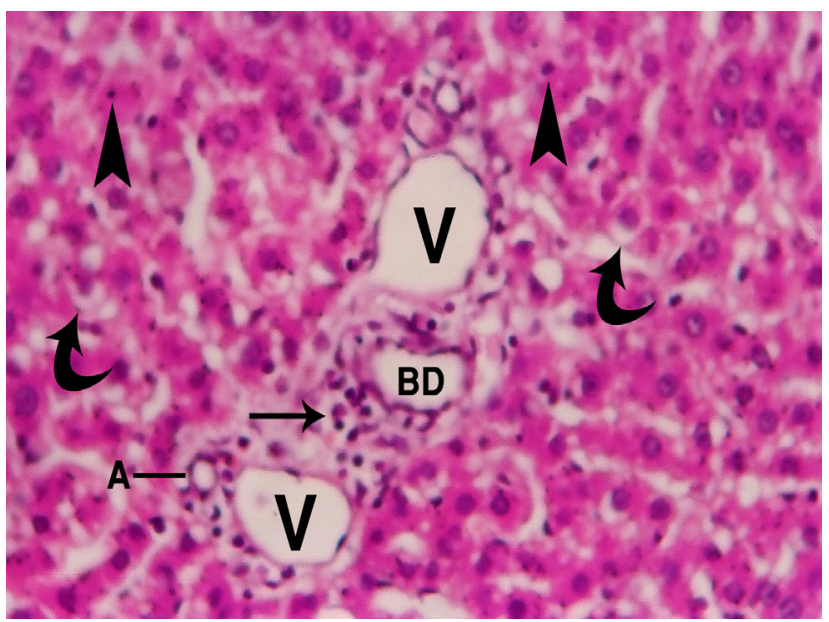

Fig. 13: A photomicrograph of a section in the liver of a rat of group IV showing few inflammatory cell infiltrate in the portal tract $(\uparrow)$, some hepatocytes show vacuolated cytoplasm (bent arrow), pyknotic nuclei (arrow heads). Notice branches of portal vein $(\mathrm{V})$, bile duct $(\mathrm{BD})$ and hepatic artery $(\mathrm{A})$.

(H\&E X x 400). cytoplasm (R) 


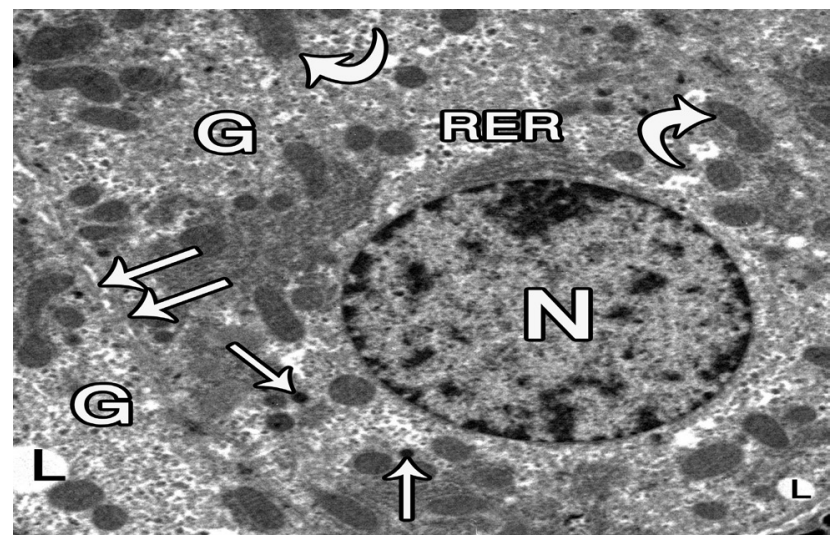

Fig. 14: An electron micrograph of a section in the liver of a rat of group IV showing two adjacent hepatocytes. The nucleus (N) is rounded in shape with regular nuclear membrane. The cell membrane $(\uparrow \uparrow)$ surrounds cytoplasm which is rich in cell organelles as mitochondria (bent arrow) rough endoplasmic reticulum (RER) and lysosomes ( $\uparrow$ ). Lipid droplets (L) and glycogen particles $(\mathrm{G})$ are present

(x 11700)

\section{DISCUSSION}

The results of the present study demonstrated that the animals taken NS oil (Group II) showed nearly the same results as the control group indicating its safety use. Also daily NS oil treatment of rats markedly improved the cisplatin-induced liver dysfunction and hepatotoxicity as confirmed by microscopic examination and biochemical assay.

Cisplatin is one of the most active cytotoxic agents in the treatment of cancer. In spite of its clinical usefulness, there are many occasions in which it is difficult to continue the administration of the drug due to its nephrotoxicity and neurotoxicity. Other less frequent toxic effects, as hepatotoxicity, which is generally observed after administration of high doses of cisplatin, can also alter the clinical situation of patients ${ }^{[28,29]}$. In the present study, cisplatin injection produced damage in the liver, as assessed microscopically and by biochemical study.

The LM hepatic changes in cisplatin-received animals showed vacuolation vacoulation of cytoplasm, some pyknotic nuclei and aggregation of inflammatory cells at portal tracts and beside central veins. These findings are in accordance with other investigarors ${ }^{[30]}$.

EM examination of cisplatin-received animals (Group III) revealed some pyknotic nuclei, secondary lysosomes, and degenerated mitochondria with cristolysis. Some area of the cytoplasm showed rarefaction, lipid droplets and vacuoles. Other investigators found some of these changes ${ }^{[30-32]}$.
Also there was elevation of liver function tests in the form of highly significant increase of serum ALT and AST which reflected hepatic dysfunction in this group and this is in accordance with other authors $^{[28]}$. The aminotransferases (transaminases) are sensitive indicators of liver cell injury and are most helpful in recognizing acute hepatocellular diseases such as hepatitis. These transaminases are present in hepatocytes and leak into the blood with liver cell damage. Aspartate aminotransferase is mostly a mitochondrial enzyme $(80 \%)$ and is also present in muscle, heart, brain and kidney. High levels of transaminases are seen in hepatic necrosis, myocardial infarction, muscle injury and congestive heart failure. Alanine aminotransferase is a cytosol enzyme, more specific to the liver so that a rise only happens with liver disease ${ }^{[33]}$.

Hepatoxicity of cisplatin has been attributed to oxidative damage due to the generation of reactive oxygen species $(\mathrm{ROS})^{[34]}$. It was shown that lipid peroxidation and depletion of glutathione (GSH) occurs following cisplatin treatment in the liver tissue ${ }^{[35]}$. GSH is an important part of the non-enzymatic antioxidant system, and it was known to play an important role in the elimination of cisplatin ${ }^{[1]}$. Therefore, decreased GSH level could also be a direct contributing factor in cisplatin-induced lipid peroxidation.

Alteration of enzymatic part of antioxidant defense systems in the liver was also reported in cisplatin hepatotoxicity. Cisplatin can inhibit superoxide dismutase, catalase and glutathione peroxidase activities and increase malondialdehide (MDA) level in the liver of $\operatorname{rat}^{[29,36]}$. These reports suggested that cisplatin could induce oxidative stress and decreased antioxidant defense mechanism leading to lipid peroxidation in the liver. So, EM findings in group III can be attributed to cisplatin-induced lipid peroxidation.

The focal increase of inflammatory cells around some central veins and at portal tracts can be attributedmay be due to elimination of the degenerated and \& necrotic hepatocytes and protection of other hepatocytes. Some authors stated that inflammation is a protective response intended to eliminate the initial cause of cell injury as well as the necrotic cells and tissues resulting from the original insult. It accomplishes its protective mission by diluting, destroying or otherwise neutralizing harmful agents, thus allowing tissue repair to take place ${ }^{[37]}$.

In the present work, the results demonstrated that treatment with NS oil ameliorated the degenerative changes in liver tissue. A significant improvement in the biochemical changes was noticed regarding ALT enzyme which is more specific for the liver, while 
AST enzyme (which is less specific for liver) was still elevated above the normal level.

Gökce et al.$^{[38]}$ reported that both the NS oil and TQ inhibit lipid peroxidation in liposomes. Lipid peroxidation prohibits the function of membrane bound enzymes and receptors ${ }^{[39]}$. In addition, NS oil has antioxidant, free radical scavenger features, antiinflammatory and antiapoptotic properties ${ }^{[38]}$. The antioxidant action of NS or TQ may also explain the protective effect of these agents against various cardiotoxic drugs ${ }^{[40]}$.

The previous authors ${ }^{[40]}$ stated that NS oil reversed the rise of MDA levels to a large extent. This gives the explanation why NS oil prevented the lipid peroxidation due to the cyclosporine A (CsA)induced cardiotoxic effect in rats. Also, the increment in the protein carbonyl content, a marker of cellular protein oxidation, was suppressed in the CsA and NS oil treated rats compared to the CsA-treated rats, and this confirms the antioxidant effect of NS oil in amelioration of cardiotoxicity.

Mahmood et al. ${ }^{[41]}$ stated that the aqueous extract of NS seeds exhibited an inhibitory effect on nitric oxide production by murine macrophages. Many studies have revealed that the modulation of the balance between nitric oxide (NO) production and lipid peroxidation products might play a major role in the increase of drug-induced cytotoxic effect ${ }^{[42,43]}$. It has been postulated that the disturbance of the balance between nitric oxide, superoxide concentration and the consequent formation of peroxinitrite may play a potential role in drug cytotoxic effect ${ }^{[44,45]}$.

The protective effect of NS oil obtained in this study is in accordance with other previous studies, ${ }^{[46]}$ who stated that (NS) is a potent antioxidant capable of scavenging hydroxy, peroxy and 1,1-diphenyl-2picrylhydrazyl free radicals and thus inhibited radicalmediated lipid peroxidation. Also, other authors ${ }^{[47]}$ postulated that the neuroprotective effects of NS and especially TQ are attributed to its direct and indirect antioxidant actions.

However, it was stated that NS oil administration has a protective effect against the carbon tetracholoridemediated suppression of hepatic cytochrome P450 enzymes and this beneficial protective effect was partly due to the down-regulation of $\mathrm{NO}$ production and up-regulation of the interleukin-10 which has antiinflammatory action ${ }^{[48,49]}$.

Other investigators found that TQ protects liver from injury via different mechanisms including increase the total thiol content and glutathione level, increasing the activity of quinone reductase, catalase, superoxide dismutase and glutathione transferase, inhibition of necrosis factor- $\kappa \mathrm{B}$ activity, inhibition of iron-dependent lipid peroxidation, radical scavengering, and inhibition of both lipoxygenase and cyclooxygenase. They postulated that, this finding makes TQ a promising prophylactic agent against chemical carcinogenesis and toxicity ${ }^{[50]}$. Moreover, it was suggested that TQ inhibits tumor angiogenesis and tumor growth, it could be used as a potential drug candidate for cancer therapy ${ }^{[51]}$

\section{CONCLUSION}

The current study confirmed the hepatotoxicity effect of the therapeutic dose of cisplatin (histologically and biochemically) which could be ameliorated by NS oil. So, it is better to cancer- patient treated treatment by cisplatin should be accompanied to take with a suitable dose of NS oil for its protective effect in one hand and anti-tumor effect in the other hand.

\section{CONFLICT OF INTEREST}

There are no conflicts of interest.

\section{REFERENCES}

1. Chu E, Sartorelli AC. Cancer chemotherapy. In: Katzung BG, Trevor AJ. Editors, Basic and clinical pharmacotherapy, $13^{\text {th }}$ ed., McGraw-Hill Education, New York 2015; 925- 927.

2. Sweetman SC.: Antineoplastics, cisplatin, In: Martindale, The Complete Drug Reference. $37^{\text {th }}$ ed., Pharmaceutical Press, UK and USA. 2011; pp $764-767$.

3. Royal Pharmaceutical Society. British National Formulary (BNF), Malignant disease, cisplatin, Pharmaceutical Press, London, UK. 2015; P 768.

4. Lee CK, Park KK, Hwang JK, Lee SK, Chung WY. The extract of Prunus persica flesh (PPFE) attenuates chemotherapy-induced hepatotoxicity in mice. J Phytother Res 2008a; 22: 223- 227.

5. Chirino YI, Pedraza-Chaverri J. Role of oxidative and nitrosative stress in cisplatin-induced nephrotoxicity. J Exp Toxicol Pathol 2009; 61 (3):223- 242 .

6. Houghton PJ, Zarka R, Heras B, Hoult RS. Fixed oil of Nigella sativa and derived thymoquinone inhibit eicosanoid generation in leucocytes and membrane lipid peroxidation. J Planta Med 1995; 61: 33- 36 
7. Kruk I, Michalska T, Lichszteld K, Kladna A, Aboul-Enein HY. The effect of thymol and its derivatives on reactions generating reactive oxygen species. J Chemosphere 2000; 41: 1059- 1064.

8. Al-Ghamdi MS. The anti-inflammatory, analgesic and antipyretic activity of Nigella sativa. J Ethnopharmacol 2001; 76: 45- 48.

9. El-Kadi A, Kandil O. The black seed (Nigella sativa) and immunity: its effect on human $\mathrm{T}$ cell subset. J Fed Proc 1987; 46: 12- 22.

10. Ugur AR, Dagi HT, Ozturk B, Tekin G, Findik D. Assessment of In vitro antibacterial activity and cytotoxicity effect of Nigella sativa oil. Pharmacogn Mag 2016; 12 (4): S471-S474.

11. Ali M, Abou Eldahab M, Mansour HA, Nigm A. Schistosoma mansoni: antiparasitic effects of orally administered Nigella sativa oil and/ or chroococcus turgidus extract. Acta Biologica Hungarica 2016; 67(3):247- 260.

12. Hebi M, Zeggwagh N, Benaji B, Michel JB, Eddouks M. Cardiovascular effect of Nigella sativa L. aqueous extract in normal rats. Cardiovasc Hematol Disord Drug Targets 2016; Jul 29 (In press)

13. Alimohammadi S, Hobbenaghi R, Javanbakht J, Kheradmand D, Mortezaee R, Tavakoli M, Khadivar F, Akbari H. Protective and antidiabetic effects of extract from Nigella sativa on blood glucose concentrations against streptozotocin (STZ)-induced diabetic in rats: an experimental study with histopathological evaluation. Diagnostic Pathology 2016; 11:125.

14. Adam GO, Rahman MM, Lee SJ, Kim GB, Kang HS, Kim JS, Kim SJ. Hepatoprotective effects of Nigella sativa seed extract against acetaminopheninduced oxidative stress. Asian Pac J Trop Med 2016; 9 (3):221 -227.

15. Mabrouk A, Bel Hadj Salah I, Chaieb W, Ben Cheikh H. Protective effect of thymoquinone against lead-induced hepatic toxicity in rats. Environ Sci Pollut Res Int 2016; 23 (12):12206- 12215.

16. Kanter M, Demir H, Karakaya C., Ozbek H. Gastroprotective activity of Nigella sativa L oil and its constituent, thymoquinone against acute alcohol-induced gastric mucosal injury in rats. World J Gastroentero 2005; 11(42): 6662 -6666.
17. Kanter M, Coskun O, Uysal H. The antioxidative and antihistaminic effect of Nigella sativa and its major constituent, thymoquinone on ethanolinduced gastric mucosal damage. Arch Toxicol 2006; 80(4): 217- 224.

18. Majdalawieh AF, Fayyad MW. Recent advances on the anti-cancer properties of Nigella sativa, a widely used food additive. J Ayurveda Integr Med 2016; 7(3): $170-180$.

19. Beheshti F, Khazaei M, Hosseini M. Neuropharmacological effects of Nigella sativa. AJP 2016; 6 (1): 124 -141.

20. Hosseinian S, Rad AK, Hadjzadeh MAR, Roshan NM, Havakhah S, Shafiee S. The protective effect of Nigella sativa against cisplatin-induced nephrotoxicity in rats. AJP 2016; 6 (1) 44 -54.

21. Al-Gharably M, Badary OA, Nagi MN, AlShabanah OA, Al-Sawaf HA, Al-Rikabi AC, AlBekairi AM. Protective effect of thymoquinone against carbon tetrachloride-induced hepatotoxicity in mice. J Res Commun Pharmacol Toxicol 1997; 2: 41- 50.

22. Kheirouri S, Hadi V, Alizadeh $M$ Immunomodulatory effect of Nigella sativa oil on $\mathrm{T}$ lymphocytes in patients with rheumatoid arthritis. Immunol Invest 2016; 45(4):271 -283.

23. Ali BH, The effect of Nigella sativa oil on gentamicin nephrotoxicity in rats. The American Journal of Chinese Medicine 2004; 32 (1): 49 -55.

24. Huang QRT, Dunn S, Jayadev OD, Pack FD et al. Assessment of cisplatin induced nephrotoxicity by micro array technology. Toxcicol Sci 2001; 63:196- 207.

25. Hayat MA. Chemical fixation. In: Hayat MA, editors. Principles and techniques of electron microscopy: biological applications. Ch $2.4^{\text {th }} \mathrm{ed}$. UK: Cambridge University Press, 2000; pp 4 -84.

26. Bancroft JD, Layton C. The hematoxylin and eosin. In: Suvarna SK, Layton C, Bancroft JD, editors. Theory \& practice of histological techniques. Ch 10. $7^{\text {th }}$ ed. Philadelphia, Churchill Livingstone; 2013; pp 172- 186.

27. Woods AE, Stirling JW. Transmission electron microscopy applications. In: Layton $\mathrm{C}$, Bancroft JD, editors. Theory and practical histological techniques. Ch 22, $7^{\text {th }}$ ed. Philadelphia, Churchill Livingstone, 2013; pp 493 - 538. 
28. Hesketh MA, Twaddell T, Finn A. A possible role for cisplatin (DDP) in the transient hepatic enzyme elevation noted after ondansetron administration. J Proc Am Assoc Clin Oncol 1990: 9: 323.

29. Koc A, Duru M, Ciralik H, Akcan R, Sogut S. Protective agent, erdosteine, against cisplatininduced hepatic oxidant injury in rats. J Mol Cell Biochem 2005; 278: 79- 84

30. Kamble PR, Bhiwgade DA. Cisplatin induced histological and ultrastructural alterations in liver tissue of rat. J Cytol Histol 2011, 2:6, 5p.

31. Martins NM, Santos NA, Curti C, Bianchi ML, Santos AC. Cisplatin induces mitochondrial oxidative stress with resultant energetic metabolism impairment, membrane rigidification and apoptosis in rat liver. J Appl Toxicol 2008; 28: 337- 344

32. Custódioa JBA, Cardosoa CMP, Santosb MS, Almeidaa LM, Vicentec JAF, Fernandesd MAS. Cisplatin impairs rat liver mitochondrial functions by inducing changes on membrane ion permeability: Prevention by thiol group protecting agents. Toxicology 2009; 259:18 -24

33. Pratt DS. Evaluation of liver function. In: Kasper DL, Hauser SL, Jameson JL, Fauci A, Longo DL, Loscalzo J. editors. In: Harrison's principle of internal medicine, $19^{\text {th }}$ ed. New York, Mc Graw Hill education, 2015; pp 1995-1998,

34. Iraz M, Ozerol E, Gulec M, Tasdemir S, Idiz N, Fadillioglu E, Naziroglu M, Akyol O. Protective effect of caffeic acid phenethyl ester (CAPE) administration on cisplatin-induced oxidative damage to liver in rat. 2006; J Cell Biochem Funct 24: 357-361

35. Pratibha R, Sameer R, Rataboli PV, Bhiwgade DA Dhume CY. Enzymatic studies of cisplatin induced oxidative stress in hepatic tissue of rats. Eur J Pharmacol 2006; 532: 290- 293.

36. Mansour HH, Hafez HF and Fahmy NM. Silymarin modulates cisplatin-induced oxidative stress and hepatotoxicity in rats. J Biochem Mol Biol 2006; 39: 656 -661.

37. Stayer DS, Rubin E, Saffitz JE, Schiller AL. Rubin's pathology, clinicopathological foundations of medicine. Ch 2, $7^{\text {th }}$ ed. Woters Kluwer, Philadelphia, Baltimore, New York and London, 2015; pp 55- 57.
38. Gökce EC, Kahveci R, Gökce A, Cemil B, Aksoy N, Sargon MF, Kısa Ü, Erdoğan B, Güvenç Y, Alagöz F, Kahveci O. Neuroprotective effects of thymoquinone against spinal cord ischemiareperfusion injury by attenuation of inflammation, oxidative stress, and apoptosis. J Neurosurg Spine 2016; 24(6):949- 959.

39. Hassan W, Noreen H, Khalil S, Hussain A, Rehman S, Sajjad S, Rahman A, da Rocha JB. Ethanolic extract of Nigella sativa protects Fe(II) induced lipid peroxidation in rat's brain, kidney and liver homogenates. Pak J Pharm Sci 2016; 29(1): 231- 237.

40. Ebru U, Burak U, Yusuf E, Reyhan B, Arif K, Faruk TH, Emin M, Aydin K, Atilla I, Semsettin S, Kemal E. Cardioprotective effects of Nigella sativa oil on cyclosporine A-induced cardiotoxicity in rats. J Basic \& Clinical Pharmacology \& Toxicology 2008; 103:574- 580.

41. Mahmood MS, Gilani AH, Khwaja A, Rashid A, Ashfaq MK. The in vitro effect of aqueous extract of Nigella sativa seeds on nitric oxide production. J Phytother Res 2003; 17: 921- 924.

42. Pacilio C, Florio S, Pagnini U, Crispino A, Claudio PP, Pacilio G, Pagnini G. Modification of membrane fluidity and depolarization by some anthracyclines on different cell lines. J Anticancer Res 1998; 18(6A): 4027- 4034.

43. Pagnini U, Florio S, Lombardi $\mathrm{P}$, d'Angelo D, Avallone L, Galdiero M, Iovane G, Tortora G, Pagnini G. Modulation of anthracycline activity in canine mammary tumour cells in vitro by medroxyprogesterone acetate. J Res Vet Sci 2000; 69: 255- 262.

44. Vasquez-Vivar J, Martasek P, Hogg N, Masters BS, Pritchard KAJ, Kalayanaraman B. Endothelial nitric oxide synthase dependent superoxide generation from adriamycin. J Biochemistry 1997; 36: $11293-11297$.

45. Pagnini U, Pacilio C, Florio S, Crispino A, Claudio PP, Giordano A, Pagnini G. Medroxyprogesterone acetate increases anthracyclines uptake in chronic lymphatic leukaemia cells: role of nitric oxide and lipid peroxidation. J Anticancer Res 2000; 20: $33-42$

46. Mohebbati R, Shafei MN, Soukhtanloo M, Roshan NM, Rad AK, Anaeigoudari A, Hosseinian S, Karimi S, Beheshti F. Adriamycin-induced 
oxidative stress is prevented by mixed hydroalcoholic extract of Nigella sativa and Curcuma longa in rat kidney. AJP 2016; 6 (1): 86 -94.

47. Kanter M. Effects of Nigella sativa and its major constituent, thymoquinone on sciatic nerves in experimental diabetic neuropathy. J Neurochem Res 2008; 33: 87- 96.

48. Ibrahim ZS, Ishizuka M, Soliman M, El Bohi K, Sobhy W. Muzandu K, Elkattawy AM, Sakamoto KQ, Fujita S. Protection by Nigella sativa against carbon tetrachloride-induced downregulation of hepatic cytochrome $\mathrm{P} 450$ isozymes in rats. Jpn $\mathrm{J}$ Vet Res 2008; 56 (3): 119 -128.

49. Al-Seeni MN, El Rabey HA, Zamzami MA, Alnefayee AM. The hepatoprotective activity of olive oil and Nigella sativa oil against CC14 induced hepatotoxicity in male rats. BMC Complementary and Alternative Medicine 2016; 16: $438-451$.

50. Mollazadeh $\mathrm{H}$, Hosseinzadeh $\mathrm{H}$. The protective effect of Nigella sativa against liver injury: a review. Iran J Basic Med Sci 2014; 17:958- 966.

51. Yi T, Cho SG, Yi Z, Pang X, Rodriguez M, Wang Y, Sethi G, Aggarwal BB, Liu M. Thymoquinone inhibits tumor angiogenesis and tumor growth through suppressing AKT and extracellular signal-regulated kinase signaling pathways. J Mol Cancer Ther 2008; 7 (7): 1789 -1796. 


\title{
الملخص العربى
}

\section{دراسة بالمجهر الضوئي والإكتروني علي التأثير الوقائي المحتمل لزيث حبة البركة على التسمم

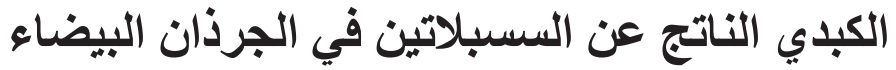

\section{ميسرة محمود سالمَ وزينب محمد الطيب2}

\author{
1قسم الأنسجة وبيولوجيا الخلية ـ كلية الطب ـ جامعة بنها ـ بنها ـ مصر \\ 2قسم الأنسجة ويبيولوجيا الخلية ـ كلية الطب ـ جامعة حلوان - حلوان - مصر
}

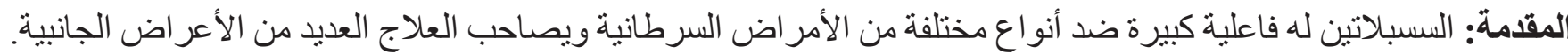

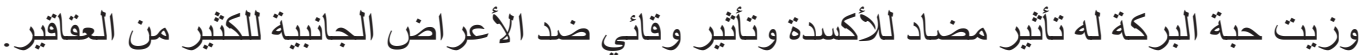

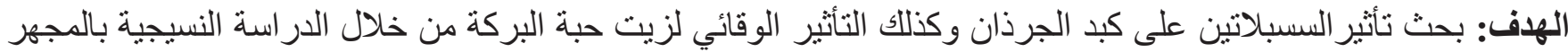

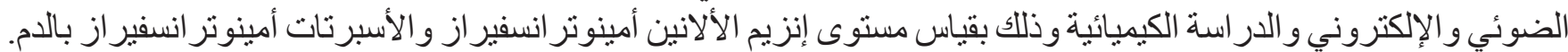

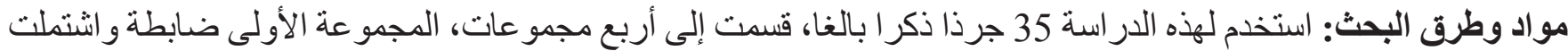

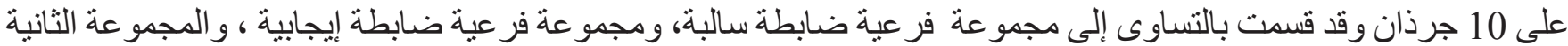

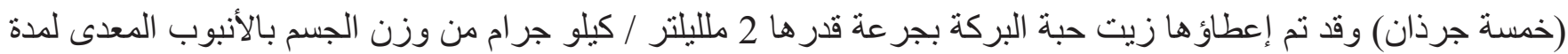

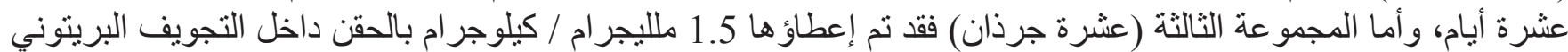

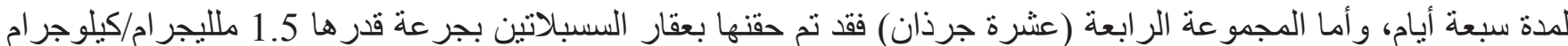
لمدة سبعة أيام وزيت حبة البركة بجر عة قدرها 2 ملليلتر / كيلوجر ام بالأنبوب المعدى لمداب لمدة عشرة أيام تبدأ قبل إعطاء عقار

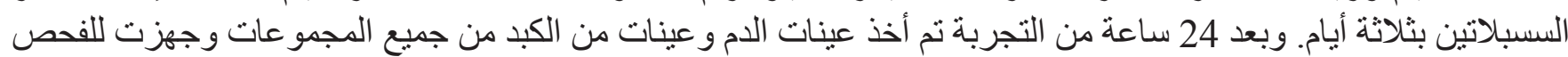
بالمجهر الضوئي و الإلكتروني.

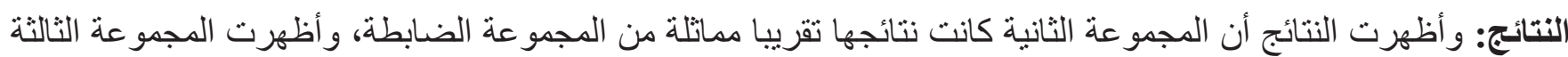

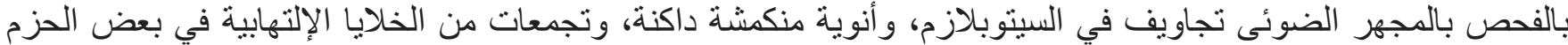

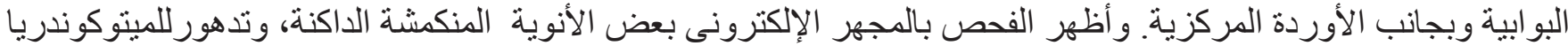

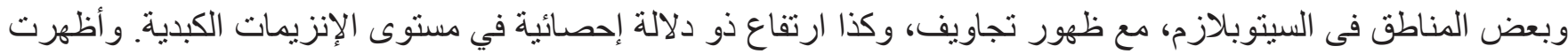

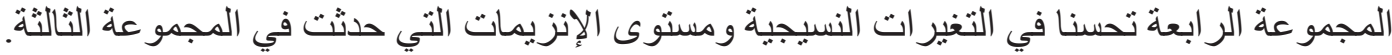
الخلاصة: زيت حبة البركة يحسن التأثنير الكبدى السام للسسبلاتين. 